\section{Risk and Risk Management in the Hungarian Sheep Sector}

\author{
Hajnalka Madai \\ University of Debrecen, Centre for Agricultural Sciences, \\ Faculty of Agricultural Economics and Rural Development, \\ Department of Farm Business Management, Debrecen \\ hmadai@agr.unideb.hu
}

\section{SUMMARY}

The aim of this paper is to give an overview of the risk attitudes of Hungarian sheep producers regarding the changes they have had to go through since the political changes of 19891990. Moreover, the objective of this study is to strengthen the empirical basis for risk analysis by identifying the importance of farmers' risk attitudes. The results of a nationwide survey of over 500 sheep farmers presented a framework of risk attitudes, risk sources and applied risk management techniques of livestock producers.

Keywords: risk sources, risk management, sheep farming, EU accession, field survey

\section{INTRODUCTION}

It is acknowledged that risk and uncertainty play an important role in agriculture world-wide. Farmers and producers are exposed to the difficulties of the market environment mainly in countries with changing and developing market economies. The need to uncover the sources of risk and uncertainty in agriculture is an inevitable managerial task, and this was especially the case under the unregulated circumstances that emerged after the collapse of Hungarian agriculture that occurred in the 1990s. Farmers found themselves within new land-, ownership-, and tax conditions which required conscious entrepreneurial behavior and thinking. Consequently, farmers have had to confront new risk sources and uncertainties given by the new and special market environment in Hungary.

Additionally, the preparation for EU accession with its risk factors has emerged as a new challenge for the Hungarian farmer. Agriculture is also an open-air system, and is therefore greatly exposed to unfavorable and uncertain physical environmental factors, such as weather and rain. Farmers deal with sensitive living creatures during their work, which is also a risk factor in their businesses.

After the political change, the Hungarian sheep sector went through a sharp transition from a regulated - but safe - so-called planned economy, into an unknown challenge: the so-called market economy. Farmers have to accept the new situation and adapt to its new economic rules. Agriculture as an industry lost a huge part of its assets by the collapse of co-operatives and state farms. The animal production population decreased by half in all branches. Sheep production, a neglected sector, lost more than half of its sheep population, which was 2.2 million in 1987, and only 734000 in 1997 (Jávor et al., 2001a). Privatization was not able to solve the problems that emerged after the collapse. For example, concentration and population density have also became a problem, because $52 \%$ of sheep farmers own less than 60 ewes, which is far from the economies of scale (350-400 ewes per farmer). Before the political change, thousands of ewes were bred on state farms. There was no remarkable diversification for different production purposes in the sheep sector, which means that $90 \%$ of the sheep population is made up of merinos, a trial purpose sheep variety, without eligible efficiency. The biggest difficulty was the lack of capital and subsidies after 1990, and it is still exists in the sheep sector. The only asset which is definitely given is the grassland area of over 1,4 million hectares - which has an unfavorable ownership system (Jávor et al., $2001 \mathrm{~b}$ ). We also have to mention the human resource problem and its skills and qualifications. Due to the exposed working conditions, becoming a shepherd is not an attractive carrier and no special shepherd training schools have existed for the last 10 years in Hungary. Because of a lack of sellable goods, there was a notable decrease in our marketed sheep products as well, when the demand and quotas were increased, but the direction of marketing was not changed (Italy, Germany, Greece) during the 1990s. Unfortunately, domestic consumption was and still is very low, only $0.2-0.3 \mathrm{~kg} /$ capita, so sheep and lamb meat are not popular in Hungary, and these are also expensive goods.

On this basis, sheep farming is especially exposed to general and special uncertainties and risk factors in Hungary, so producers have to apply different risk management strategies, depending on the scale and purpose of their sheep production businesses.

In our paper, we tried to find out Hungarian livestock farmers risk aversions and their ability to handle and manage risk in their businesses.

\section{DATA AND METHOD}

The method was based on a representative national field survey involving $10 \%$ of sheep farmers and $80 \%$ of sheep farms in the Hajdú-Bihar Region (and makes 1/3 of the Hungarian Sheep Population). The questionnaire as a tool of data collection included three main parts, adjusted according to the possible sources of risk, applied risk management techniques and property and personal information about the farmer. Farmers involved in the survey were asked to evaluate risk factors and risk sources according to their importance for them. Another task 
was for them to suggest solutions and techniques to avoid or reduce risk in their production under the given conditions.

First, farmers were asked to evaluate 5 general and 32 special most possible risk sources on a 5 -scored Linkert-scale. These potential sources were listed according to the categories in Table 1. In the second section, they had to choose from 32 listed management techniques which they applied to avoid or decrease risk in sheep farming. The applied techniques were also evaluated according to their importance in a 5-scored Linkert-scale. The listed sources of risk and risk management techniques were gathered from the literature (Martin, 1996) to complete with factors coming from Hungarian national and geographical endowments. The grouping of risk sources and management techniques was also based on literature (Gabriel and Baker, 1980; Sonka and Patrik, 1984) (Table 1).

Categories of Risk Sources and Risk Management Techniques

\begin{tabular}{|c|c|c|c|c|c|}
\hline \multicolumn{4}{|c|}{ BUSINESS RISK } & \multirow[b]{2}{*}{ FINANCIAL RISK } & \multirow{2}{*}{$\begin{array}{c}\text { RISK MANAGEMENT } \\
\text { TECHNIQUES }\end{array}$} \\
\hline Production & Market & $\begin{array}{c}\text { Institutional/ } \\
\text { legal-social }\end{array}$ & Personal/Human & & \\
\hline $\begin{array}{l}\text { - type } \\
\text { - technological and } \\
\text { environmental } \\
\text { conditions and } \\
\text { circumstances }\end{array}$ & $\begin{array}{l}\text { - prices of outputs } \\
\text { and inputs } \\
\text { - cooperation }\end{array}$ & $\begin{array}{l}\text { - regulations } \\
\text { - restrictions } \\
\text { - laws } \\
\text { - supports } \\
\text { - information } \\
\text { - contracting } \\
\text { - insurance } \\
\text { - security }\end{array}$ & $\begin{array}{l}\text { - age } \\
\text { - attitude } \\
\text { - family } \\
\text { - background } \\
\text { - education and } \\
\text { skills }\end{array}$ & $\begin{array}{l}\text { techniques and } \\
\text { methods of dealing } \\
\text { with finance } \\
\text { - debt and payment } \\
\text { management } \\
\text { - diversity of } \\
\text { investment }\end{array}$ & $\begin{array}{l}\text { - production } \\
\text { - marketing } \\
\text { - financial }\end{array}$ \\
\hline
\end{tabular}

On the base on Gabriel and Baker (1980), and Sonka and Patrik (1984)

The third section of the questionnaire covered the main information about the person, land, animals, material and financial sources, costs and debt conditions of the farm.

The evaluation of the gathered data was made by basic statistics (SPSS 10, MS Excel 5.0).

\section{RESULTS}

Within the survey, we obtained 520 questionnaires and 516 were suitable for preparation. Farmers were selected according to the number of ewes owned (as a measure of farm size). Distribution of the farms is shown on Figure 1.

Figure 1: Distribution of Studied Farms According to their Ewe Number

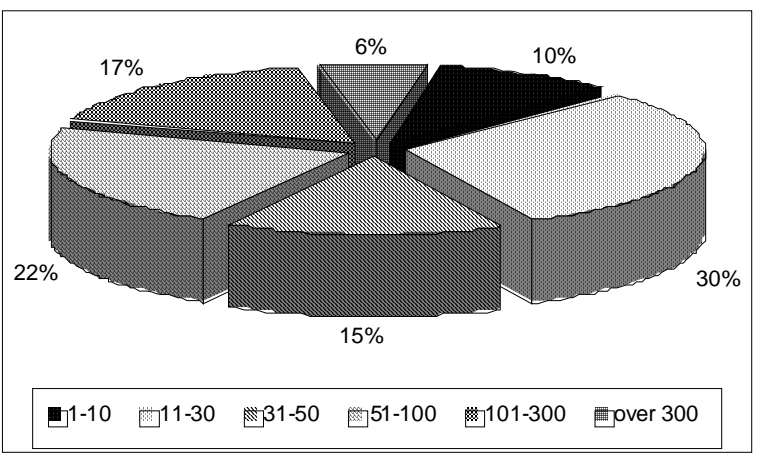

Only $6 \%$ of the sheep farmers own more then 300 ewes in a flock, which can be the limit of the economic size of sheep farming. This also means that sheep farming is, in most cases, only a part time job for farmers and retired farmers. Another interesting statistic is the average age of the farmers, which was
48 years. Additionally, most sheep farmers had already retired.

$85 \%$ of the enterprises were individual without any labor and only $2 \%$ of them were operated in any kind of company or corporation.

Most of them had land and pasture as well. $80 \%$ of them hire the pasture and only $20 \%$ own it. $60 \%$ of farmers use less then 10 hectares of pasture and only $4 \%$ of them use more than 100 hectares. $92 \%$ of the farmers said that they had no debts.

\section{RISK SOURCES}

Risk in sheep farming may emanate from a number of sources. These include mainly production (or technological) risk, financial risk, price risk and human risk as well. Production risk is the variability inherent in the production process itself. It can include unfavorable weather conditions, diseases, pest infestations, and of course the special characteristics of the animals for breeding. (Hardaker et al., 1998). This type of risk impacts on profit and yields. On the other hand, price risk is associated with fluctuations in the price of purchased inputs (feeding stuffs, transportation and veterinary services) and saleable outputs (lamb, mutton, milk, wool, breeding animals, dung), and impacts on profit through input costs and output prices. The combined risk from both of these sources is termed business risk, and tends to be reflected in variability in the net operating income (or net cash flow) of the farm business.

Producers' assessment of production risks was not quite uniform regarding the different production conditions. They made a differentiation according to the quality and the quantity of their pasture and 
production area, size and type of the flock of their sheep.

Financial risk is essentially the risk being unable to meet prior claims with the cash generated by the farm, and is determined by the dispersion of net cash flows, the level of debt, and other pools of financial resources. The components of financial risk used to be the most severe in the evaluations given by the producers. The level of capital and the obtaining of debt might especially make up the biggest problems of their businesses.

Marketing and price risk were also emphasized as main sources of risk in sheep farming, because of contracting practice and the uncertainty and fluctuations of lamb market prices. Furthermore, the information about prices and market trends influence a farmer's economic possibilities. The traditional view of risk, which divided sources of risk into production, price and financial risks allow the impact of each of these sources of risk on the farm operation. This can be clearly traced by observing the influence on yield, output prices and input costs, and residual cash flows to the owners' equity. The risk associated with government policy slowing down the pace of its economic reforms and subsidies, and leaving agriculture or the sheep sector in a relatively disadvantaged position is likely to have implications for on-farm management decisions, as occurred in the 1990s in Hungary.

Other less obvious sources of risk can also be envisaged. These include technological risk, legal risk and human risk. Although these additional sources of risk are less easily observed than the more familiar categories of production, price and financial risk, they nevertheless can have a crucial impact on the farm business. We can highlight the human factor, which is a big problem in sheep farming. It is very difficult to find skilled and reliable staff for sheep farms. The responsibility of staff involves taking care of newborn lambs and the quality of milking, which are both critical factors of income on a sheep farm. Human risks may come from the situation and changes in conditions of the farmer. Unexpected health problems, accidents, or changes in family situation may cause serious risk factors.

It was identified that rainfall and weather conditions are the main sources of risk for sheep farmers, as well as lamb and input prices. Table 2 shows the importance of risk sources according to the farmers' evaluation.

Rainfall and lamb prices had the highest average score 4.2 and 4.1. It was remarkable, but reasonable, that lamb prices and output were highly mentioned by sheep farmers as risk factors in their production, because lamb is the main product of Hungarian sheep sector and it is highly exposed to the Italian market. Input prices had a 3.9 average score, which is caused by the variable feed prices and the increasing energy prices during the accession period. Changes in Hungarian agricultural policy had also a relatively high score 3.5 , which also comes from the unstable subsidies and market regulations in agriculture during the last years. It was similar then in an unregulated agricultural system, but without reasonable product prices. Epidemics and theft were mentioned with an average of 3.5 score, which means their importance for sheep farmers and also protection against such occurrences is a remarkable cost.

Table 2

Importance of Different Risk Sources

\begin{tabular}{|c|c|c|c|}
\hline Risk Sources & $\begin{array}{l}\% \text { of Valid } \\
\text { Answers }\end{array}$ & Mean & Std. D. \\
\hline Rainfall during the year & 99.2 & 4.2 & 1.0 \\
\hline Changes in lamb prices & 96.7 & 4.1 & 1.0 \\
\hline Changes in input costs & 98.4 & 3.9 & 1.1 \\
\hline Other weather conditions & 99.4 & 3.6 & 1.1 \\
\hline Changes in sheep product prices & 99.2 & 3.6 & 1.2 \\
\hline $\begin{array}{l}\text { Changes in Hungarian } \\
\text { Agricultural Policy }\end{array}$ & 98.4 & 3.5 & 1.1 \\
\hline Epidemics & 98.8 & 3.5 & 1.4 \\
\hline Theft & 98.8 & 3.5 & 1.2 \\
\hline Accidents or health problems & 99.0 & 3.4 & 1.3 \\
\hline $\begin{array}{l}\text { Changes in Hungary's economic } \\
\text { situation }\end{array}$ & 98.4 & 3.4 & 1.1 \\
\hline Animal heath problems & 98.3 & 3.4 & 1.2 \\
\hline Unethical merchandise & 98.8 & 3.2 & 1.2 \\
\hline Missing lamb selling contracts & 88.4 & 3.2 & 1.4 \\
\hline Animal reproduction problems & 98.8 & 3.2 & 1.1 \\
\hline Changes in wool prices & 87.6 & 3.2 & 1.4 \\
\hline Changes in production yields & 99.2 & 3.1 & 1.1 \\
\hline $\begin{array}{l}\text { Changes international policy and } \\
\text { economy }\end{array}$ & 98.1 & 3.0 & 1.2 \\
\hline $\begin{array}{l}\text { Changes in local body law and } \\
\text { regulations }\end{array}$ & 98.3 & 2.9 & 1.1 \\
\hline Environmental regulations & 98.3 & 2.9 & 1.2 \\
\hline Natural disasters & 98.1 & 2.7 & 1.4 \\
\hline $\begin{array}{l}\text { Operation of organizations in the } \\
\text { sheep sector }\end{array}$ & 98.6 & 2.6 & 1.1 \\
\hline Operation of Production Boards & 98.4 & 2.6 & 1.2 \\
\hline $\begin{array}{l}\text { Changes in land prices and rent } \\
\text { costs }\end{array}$ & 95.2 & 2.6 & 1.4 \\
\hline Lack of integration of producers & 98.1 & 2.6 & 1.2 \\
\hline $\begin{array}{l}\text { Missing sheep milk selling } \\
\text { contracts }\end{array}$ & 79.1 & 2.5 & 1.5 \\
\hline Changing in family situation & 98.4 & 2.4 & 1.3 \\
\hline $\begin{array}{l}\text { Missing breeding animal selling } \\
\text { contracts }\end{array}$ & 66.3 & 2.3 & 1.6 \\
\hline $\begin{array}{l}\text { Breeding policy, hanging of } \\
\text { animal breeds }\end{array}$ & 98.4 & 2.3 & 1.3 \\
\hline Changing of keeping technology & 98.1 & 2.3 & 1.3 \\
\hline Breaking of contracts & 84.5 & 2.2 & 1.4 \\
\hline Changing of labor costs & 95.7 & 2.2 & 1.3 \\
\hline Selling options of by-products & 97.3 & 2.1 & 1.2 \\
\hline Changing of interest rates & 87.8 & 2.1 & 1.4 \\
\hline Changes in sheep milk prices & 67.2 & 1.8 & 1.3 \\
\hline Missing wool selling contracts & 60.5 & 1.8 & 1.3 \\
\hline
\end{tabular}

Relatively low importance was detected in risk sources regarding milk and wool. Wool is a 
byproduct, so it may serve as extra income for several years, but generally this income hardly covers the sharing costs. Milk is good product with reasonable prices and subsidy, but has such a low quantity in Hungary (1.5 million liter/year), that it cannot be a risk source for milking farmers. Breaking contracts and a lack of contracts are generally low scored factors. The reason for this is that, unfortunately, contracting is accidental in the Hungarian sheep sector and having one also does not mean safe business for the farmers.

Consequently, producers cannot influence their main risk factors, such as prices and weather conditions or financial and production risk factors.

\section{RISK MANAGEMENT}

Risk management strategies, which can reduce risk, may incorporate production, marketing and financial responses. Production response includes selecting enterprises, fields or animals, which are known to have a low yield capacity. Enterprise diversification may also be an appropriate way to reduce risk. Modification of technical and technological practices may serve also as a tool to reduce risk on the sheep farm. Selecting production aims (meat or milk production, dual purpose or trial purpose genotypes), spreading product sales over time.

Marketing responses may include contracting, selecting market or merchants. Forward contracting or hedging on the future markets allow products, and in some cases inputs, to be priced before delivery.

Changes in financial management practice can also ameliorate risk. Responses can include maintaining additional liquidity by holding more liquid assets and matching the debt repayment structure with the income generating pattern of any purchased asset. Increasing the ratio of equity capital to total assets will also reduce the financial risk associated with the farm (Martin, 1996).

Although the wide range of risk-reducing strategies may be possible in principle, the number of strategies, which are actually available to an individual farmer, is likely to be much more limited in practice. Some types of strategy may not be appropriate for a farm of a particular size or production-type, type of ownership structure, or may not be available in a particular region. Finally, the choice of an appropriate risk-reducing strategy is also likely to be influenced by flows of production, marketing and financial information and managerial skills of the farmer. In some respects, appropriate information collection and utilization might well be considered a risk reducing strategy in its own right or we can mention the personnel connections, which are difficult to measure.

The most efficient combination of enterprises and selling options may be of limited value if strategies for managing risk are perceived by producers as much less efficient than, the ability to remain flexible with respect to enterprise selection and marketing decisions, so as to be able to respond very rapidly and opportunistically to changing weather and price conditions. Sheep farming is especially exposed to general and special uncertainty in Hungary, so producers have to apply different risk management strategies depending on the scale and purpose of their sheep production. Self-producing and maintaining of feed reserves instead of buying them, applying low cost production system and keeping debt low and applying for the available government subsidies are the main risk management strategies in sheep farming. Variation exists between farmers in the importance attached to their marketing strategies, which is based on the quantity and quality of their products. But contracting is considered an important risk management strategy of sheep farmers.

As a result of the survey we have found that sheep farmers try to apply risk management techniques as it is possible under the given conditions of them. Economies of scales and lack of capital are difficulties to carry it out. Table 3 contains the most and least used risk management techniques evaluated by the sheep farmers.

The most widely applied techniques were the cooperation between farmers and joining to producer groups or integrations, which was applied by $74.4 \%$ of the farmers and scored to 3.8. Maintaining feed reserves dot a 3.5 score and was applied by $73.6 \%$ of producers. Gathering market information and monitoring were also highlighted by farmers as useable tools for decreasing risk. Security and safeguarding also obtained scores of 3.8. These techniques are in correspondence with the main sources of risks.

Table 3

Importance of Risk Management Techniques and the Percentage of Their Use

\begin{tabular}{|l|r|r|r|}
\hline & \% Use & Mean & Std. D. \\
\hline $\begin{array}{l}\text { The most frequently used } \\
\text { management techniques }\end{array}$ & $\geq 50 \%$ & & \\
\hline $\begin{array}{l}\text { Cooperation integration of } \\
\text { producers }\end{array}$ & 74.4 & 3.8 & 1.0 \\
\hline Maintaining feed reserves & 73.6 & 3.5 & 1.0 \\
\hline Up-to-date market information & 65.9 & 3.7 & 1.1 \\
\hline $\begin{array}{l}\text { Monitoring of pest, diseases, crops, } \\
\text { prices }\end{array}$ & 63.4 & 3.7 & 1.0 \\
\hline Weather forecasting & 60.7 & 3.6 & 1.0 \\
\hline Security, safeguarding & 58.3 & 3.8 & 1.0 \\
\hline $\begin{array}{l}\text { More crop variety, breed, or dual- } \\
\text { purpose animals }\end{array}$ & 58.1 & 3.5 & 1.0 \\
\hline $\begin{array}{l}\text { The least frequently used } \\
\text { management techniques }\end{array}$ & $\leq 30 \%$ & & \\
\hline Forward contracting & 28.9 & 3.4 & 1.1 \\
\hline Long-term flexibility & 27.9 & 3.2 & 1.0 \\
\hline Not producing to full capacity & 25.8 & 3.6 & 1.0 \\
\hline Irrigation of crops and grassland & 20.0 & 3.7 & 1.0 \\
\hline $\begin{array}{l}\text { Off-farm investment in other } \\
\text { industries }\end{array}$ & 18.0 & 3.7 & 1.1 \\
\hline Debt management, monitoring, & 16.3 & 3.6 & 1.0 \\
\hline Keeping debt low & 16.1 & 3.5 & 1.0 \\
\hline
\end{tabular}


The least-used techniques (applied by 16\% of the farmers) regard debt management and off-farm investment, which shows that most farmers are poor; have no equities and capital to resort debt or other investments. Irrigation and not producing to full capacity cannot be widely applied by Hungary in sheep production, where the average rate of lambing is 0.9 and irrigation is an extra cost. Therefore, farmers try to utilize all the sources they have at as low a cost as possible.

\section{CONCLUSION}

As a result of the survey, we realized that farmers were forced to re-evaluate the sources of risk which they face after the political and mainly economic changes. They try to take measures to protect their businesses against risks coming from new regulations. This is likely to have resulted in changes to traditional patterns of risk aversions and management as sheep farmers have adjusted to the new farming environment. It is clear that the external environment facing sheep farmers and producers is now fundamentally different to what it was 15 years ago, and this trend is likely to continue due to the EU accession and the changing economic environment. This was also demonstrated by this study. It was also revealed that sheep farmers are not so exposed to market regulations, because overproduction has not characterized this sector. Without production quotas, they have better survival chances than other ruminant sectors in Hungary. A possible aim for this sector would be to enhance quality meat and milk production competitiveness.

\section{REFERENCES}

Gabriel, S. C.-Baker, C. B. (1980): Concepts of Business and Financial Risk, American Journal of Agricultural Economics 62. 560-564.

Hardaker, J. B.-Huirne, R. B. M.-Anderson, J. R. (1998): Coping with Risk in Agriculture, CAB International, UK

Jávor, A.-Nábrádi, A. (2001a): Management and Economics of Sheep Production, In: Agricultural Economics Mezőgazdasági Szaktudás Kiadó, Budapest, 437-456.

Jávor, A.-Nábrádi, A.-Molnár, Gy.-Szücs, I.-Kukovics, S. (2001b): Korkép 2000. Hungarian Sheep Production (Magyar Juhászat) Vol. $10^{\text {th }} \cdot 2001 / 3.4-7$.
Martin, S (1996): Risk management Strategies in New Zealand Agriculture and Horticulture, Review of Marketing and Agricultural Economics Vol. 64, No. 1, April 1996. Australian Agricultural and Resource Economic Society, Inc. 30-44.

Sonka, S. T.-Patrik, G. F. (1984): Risk Management and Decision Making in Agricultural Firms, In Barry, O. J. et al. Risk Management in Agriculture, Iowa State University Press, Ames, Iowa. 